Doi: HTTPS://DOI.ORG/10.23910/IJEP/2019.6.1.0285

\title{
Hot Water Dipping and UV Irradiation of Apples to Control Fruit Rots
}

\author{
Neelam Kumari ${ }^{1 *}$, J. N. Sharma ${ }^{2}$ and Deepika Singh ${ }^{3}$ \\ ${ }^{1}$ Krishi Vigyan Kendra Rohru, Shimla, H.P. (171 207), India \\ ${ }^{2}$ Dept. of Plant Pathology, ${ }^{3}$ Dept. of Fruit Science, Dr. Y. S. Parmar University of Horticulture and Forestry, Nauni, \\ Solan, H.P. (173 230), India
}

\section{Corresponding Author}

Neelam Kumari

e-mail: neelkumari90@gmail.com

\author{
Article History \\ Article ID: IJEP0285 \\ Received in $12^{\text {th }}$ February, 2019 \\ Received in revised form $19^{\text {th }}$ February, 2019 \\ Accepted in final form $22^{\text {nd }}$ February, 2019
}

\begin{abstract}
The efficacy of hot water dipping and UV irradiation against apple storage rots caused by Alternaria alternata (mouldy core), Trichothecium roseum (pink mould rot), Monilinia fructigena (brown rot), Aspergillus niger (black rot) and Penicillium expansum (blue mould rot) was examined. Artificially inoculated Starking Delicious apples were incubated for $3 \mathrm{~min}$ in a water bath heated to specific temperatures in the range of $48{ }^{\circ} \mathrm{C}$ to $52^{\circ} \mathrm{C}$. Storage rots caused by all the five species were significantly reduced at dipping temperature of $48{ }^{\circ} \mathrm{C}$. UV irradiation of fruits for $15 \mathrm{~min}$ was found most effective in reducing decays caused by all the test fungi. These results suggest possible applications of hot water dipping and UV irradiation of apples at harvest, after short-term cold storage or after the opening of controlled-atmosphere storage rooms in order to reduce decays during subsequent storage periods.
\end{abstract}

Keywords: Apple, hot water dipping, irradiation, storage rots

\section{Introduction}

Apple (Malusxdomestica Borkh.) is a member of Rosaceae family and considered as one of the most economically important fruit trees of temperate zones (Martinelli et al., 2008). Agro-climatic conditions in hilly regions of Himachal Pradesh offer immense natural potential for increasing area and production under temperate fruits, especially apple. Though the area and production under apple cultivation in Himachal Pradesh has increased during the last few decades, but the productivity per unit area has not increased proportionally and is quite low as compared to the advanced apple growing countries of the world. The reasons for low apple productivity could be many, but one of them is the post harvest losses caused by different fungi.

There are different strategies for the management of post harvest losses. Among these, better post harvest handling practices and use of pre and post harvest fungicides are the major management strategies. However, use of chemical fungicides in the management of post harvest diseases poses a risk of residues in the harvest for the consumers. Use of chemicals in the management of post harvest diseases is restricted due to their possible carcinogenicity, teratogenicity, high and acute toxicity, long degradation periods, environment pollution and their effects on human beings. On the other hand, physical control measures such as hot water dippings and UV irradiation can be taken as alternatives to the prevalent chemical control measures.

Hot-water dipping (HWD) of freshly harvested apple fruit prior to long-term storage is an important strategy for the control of post-harvest diseases especially in the organic production sector (Maxin et al., 2006). Recent advances in the science and engineering of UV-light irradiation have demonstrated that UV treatment holds considerable promise for shelf-life extension of fresh fruits and vegetables.

\section{Materials and Methods}

\subsection{Fruit}

Starking Delicious apples were harvested at the preclimacteric stage from a commercial orchard in Shimla district of Himachal Pradesh. The climacteric rise in carbon dioxide production had not yet begun. The apples were randomized prior to treatment.

\subsection{Fruit inoculation}

Fruits were inoculated following Well method of Granger and Horne (1924). Wells were made on the fruit surface with the help of cork borer (internal diameter $5 \mathrm{~mm}$ ). The inoculum of $A$. alternata, T. roseum, $M$. fructigena, $A$. niger and $P$. expansum was placed at the bottom of wells and plugged back. These were further sealed with sterile paraffin wax. 


\subsection{Treatments}

\subsubsection{Hot water treatment}

Hot water dip treatments were performed in a thermostatically controlled water bath. The water bath was filled with fresh tap water for each treatment separately. Twelve hours after inoculation, each replicate was subjected to the following hot water dip treatments: $48{ }^{\circ} \mathrm{C}, 50{ }^{\circ} \mathrm{C}$, and $52{ }^{\circ} \mathrm{C}$ for 3 minutes whereas in the inoculated check, fruits were dipped in water at room temperature for 3 minutes. There were 3 replicates of each treatment with 5 fruits per replicate for a particular test fungus. Following dipping, the fruits were left to dry for 20 to 30 minutes at room temperature. After one week, per cent fruit rot was calculated after 6 days of inoculation by the formula given by Srivastava and Tandon (1968):

Per cent fruit rot $=(\mathrm{W}-\mathrm{w}) / \mathrm{W} \times 100$

Where,

$W=$ weight of the fruits before inoculation

$\mathrm{w}=$ weight of the fruits after removal of the rotten tissue

\subsubsection{UV irradiation}

Starking Delicious apples with uniform size, shape and maturity and free from any diseases were used for UV irradiation treatment. Fruits were washed with tap water, air-dried and randomly divided into four lots for UV irradiation in Laminar Air Flow Cabinet. There were 3 replicates of each treatment with 5 fruits per replicate for a particular test fungus. Twelve hours after inoculation, each replicate was subjected to the following irradiation treatments: (1) control (untreated); (2) UV irradiation for $5 \mathrm{~min}$; (3) UV irradiation for $10 \mathrm{~min}$; (4) UV irradiation for $15 \mathrm{~min}$. Following treatment, the fruits were kept at room temperature and observed for fruit rotting. Per cent fruit rot was calculated by the formula given by Srivastava and Tandon (1968) as described above.

\section{Results and Discussion}

\subsection{Effect of hot water treatment on post harvest rotting of apple}

The data regarding effectiveness of hot water at three different temperatures in controlling various fungal rots is presented in Table 1. Perusal of the data revealed that treating apples in water at $48{ }^{\circ} \mathrm{C}$ for 3 min was highly effective in controlling various fungal decays under study with per cent control of 70.79 per cent and the effectiveness got highly reduced on raising this temperature by only $4{ }^{\circ} \mathrm{C}$. The efficacy was poor at $52{ }^{\circ} \mathrm{C}$, the maximum temperature tested. However, fungal deterioration was more rapid and highest in untreated apples kept as control.

Irrespective of treatments, maximum decay in apples was observed to be caused due to $M$. fructigena (90.91\%) and minimum by $T$. roseum (29.98\%). Significant difference in virulence but in descending order existed in remaining test fungi namely, $P$. expansum (43.85\%), A. niger (42.28\%) and A. alternata (32.83\%).

The interaction between hot water treatments and inoculated apple fruits revealed further that $T$. roseum was completely eradicated at $48{ }^{\circ} \mathrm{C}$ and $50{ }^{\circ} \mathrm{C}$ and effectively controlled at 52 ${ }^{\circ} \mathrm{C}$. While $\mathrm{M}$. fructigena was completely tolerant to wet heat at 48 and $50{ }^{\circ} \mathrm{C}$ and was slightly affected at $52{ }^{\circ} \mathrm{C}$. However, hot water treatment at $48{ }^{\circ} \mathrm{C}$ was effective against $A$. alternata, $A$. niger and $P$. expansum.

Similar results of hot water dipping effect on subsequent infections by storage rot fungi were obtained for pear fruit inoculated with Mucor piriformis or Phialophora malorum (Spotts and Chen, 1987) and for grapefruit inoculated with Penicillium digitatum (Porat et al., 2000). Numerous trials have documented the efficacy of hot water dipping against Neofabraea spp. causing storage rot in apples (Burchill, 1964; Trierweiler et al., 2003; Maxin et al., 2005; Neri et al., 2009). Storage rots of apple caused by Neonectria galligena, Botrytis cinerea and Penicillium expansum were significantly reduced by hot water dipping at temperatures around $50{ }^{\circ} \mathrm{C}$. Temperatures above $52{ }^{\circ} \mathrm{C}$ caused serious heat scald on the fruit surface and gave rise to increasing levels of fruit rot in the case of $N$. galligena and P. expansum (Maxin et al., 2012). Post harvest decay of strawberries caused by $B$. cinerea and $R$. stolonifer has been controlled by exposing the fruits to humid air at $44^{\circ} \mathrm{C}$ for $40-60 \mathrm{~min}$ (Couey and Follstad, 1966). Akamine and Arisumi (1953) have reported hot water treatments for fruit rot of papaya $\left(48^{\circ} \mathrm{C}\right.$ for $\left.20 \mathrm{~min}\right)$. In apples, a fungistatic antimicrobial effect against $P$. expansum was induced by hot

Table 1: Effect of hot water treatment on post harvest rotting of apple cv. Starking Delicious

\begin{tabular}{|c|c|c|c|c|c|c|c|}
\hline \multirow[t]{2}{*}{ Treatment } & \multicolumn{5}{|c|}{ Per cent fruit rot } & \multirow[t]{2}{*}{ Mean } & \multirow{2}{*}{$\begin{array}{c}\text { Per cent } \\
\text { control }\end{array}$} \\
\hline & A. alternata & T. roseum & M. fructigena & A. niger & P. expansum & & \\
\hline $48^{\circ} \mathrm{C}$ & 6.78 & 0.00 & 100.00 & 17.76 & 21.49 & $29.21(32.70)$ & 70.79 \\
\hline $50{ }^{\circ} \mathrm{C}$ & 9.34 & 0.00 & 100.00 & 20.33 & 23.87 & 30.71 (33.64) & 69.29 \\
\hline $52{ }^{\circ} \mathrm{C}$ & 15.18 & 19.94 & 63.64 & 31.03 & 30.02 & $31.96(34.41)$ & 68.04 \\
\hline Control & 100.00 & 100.00 & 100.00 & 100.00 & 100.00 & $100.00(89.96)$ & - \\
\hline Mean & $32.83(34.94)$ & 29.98 (33.19) & $90.91(72.42)$ & $42.28(40.54)$ & $43.85(41.45)$ & - & - \\
\hline
\end{tabular}

CD $(p=0.05)$; Treatment: 0.376 ; Test pathogen: 0.376 ; Treatment $\times$ Test pathogen: $0.840 ;{ }^{*}$ Figures in parentheses are arc sine transformed values 
water dipping at $50{ }^{\circ} \mathrm{C}$ for $3 \mathrm{~min}$ and was maintained during subsequent cold-storage for 100 days whilst disappearing within 150 days (Amiri and Bompeix, 2011).

Heat may trigger the transcription not only of heat-shock proteins (HSPs) (Woolf and Ferguson, 2000), but also of pathogenesis-related proteins (PRPs) with putative or proven roles in suppressing microbial plant pathogens (Schirra et al., 2000; Pavoncello et al., 2001). In apples, HSPs have been induced by incubating fruit cell suspensions at $38^{\circ} \mathrm{C}$ for $60 \mathrm{~min}$ (Wang et al., 2001) or by hot-air treatments of intact fruit for 4 days at $38{ }^{\circ} \mathrm{C}$ (Lurie and Klein, 1990). Heat treatments (40 ${ }^{\circ} \mathrm{C}$ for 5 and 10 minutes) elicited defence responses in fruit which inhibited the growth of Monilinia fructicola and reduced overall decay in peach fruit without impairing the quality of the fruit itself (Liu et al., 2012). Overall, the effect of hot water dipping and other heat treatments in apples is best explained as a combination of the indirect fungistatic effect of induced resistance of fruit and fungicidal effect of heat on inoculum viability. Depending on experimental design, pathogen species and type of inoculum, the relative importance of these two effects in apples may differ (Fallik et al., 1995).

\subsection{Effect of UV irradiation on post harvest rotting of apple}

To study the effect of UV irradiation on post harvest rotting of apple, fruits of Starking Delicious cultivar were artificially inoculated with test fungi and exposed to UV light in Laminar Air Flow Cabinet after 12 hours of inoculation for 5, 10 and $15 \mathrm{~min}$. The per cent fruit rot thus recorded after 6 days of inoculation has been presented in Table 2.

The perusal of data revealed that UV exposure of 15 min was significantly more effective in controlling various fungal rots under study followed by UV exposure of $10 \mathrm{~min}$ with per cent control of 65.04 and $46.68 \%$, respectively. UV exposure of 5 min was the least effective in controlling the fungal decays.

Irrespective of the treatments, $100 \%$ rot was observed in the fruits inoculated with $M$. fructigena and minimum by $T$. roseum (42.28\%). P. expansum was the next virulent fungus followed by $A$. niger and $A$. alternata with mean per cent fruit rot of $74.34,56.22$ and $44.00 \%$, respectively.

The interaction between UV irradiation treatment and test fungi revealed that $M$. fructigena was completely tolerant to UV irradiation. UV exposure of 15 min was significantly more effective in reducing the fungal decays caused by $A$. alternata, $T$. roseum and $A$. niger whereas, it was the least effective in controlling $P$. expansum.

When tested for its application on apple and pear cultivars, lower dose irradiation reduced decay on apples caused by $P$. expansum by up to $80 \%$ but failed to have any impact on disease incidence caused by $B$. cinerea. Furthermore, the firmness of the apple was lost to some extent while the outer colour was not affected, there was noticeable colour change to the inside flesh of the apples due to irradiation exposure (Drake et al., 1998).

It has been seen that multicellular conidia of Alternaria and Stemphylium or bicellular spores such as Cladosporium and Diplodia are more resistant to gamma radiation than the unicellular spores of other fungal species (Sommer et al., 1964). Since radiation can penetrate fruit tissues, it has a therapeutic effect. Plant tissues can also produce phytoalexins (defence chemicals) in response to radiation effect. Low doses of UV-C light (wavelength 190-280 nm) can induce resistance in a wide range of fruits and vegetables (Barkai-Golan, 2001). UV light has a germicidal effect and, at the same time, it induces activity of PAL and peroxidase enzymes (Droby et

\begin{tabular}{|c|c|c|c|c|c|c|c|}
\hline \multirow[t]{2}{*}{ Treatment } & \multicolumn{5}{|c|}{ Per cent fruit rot } & \multirow[t]{2}{*}{ Mean } & \multirow{2}{*}{$\begin{array}{l}\text { Per cen } \\
\text { control }\end{array}$} \\
\hline & A. alternata & T. roseum & M. fructigena & A. niger & P. expansum & & \\
\hline $5 \mathrm{~min}$ & 41.36 & 36.26 & 100.00 & 65.67 & 82.68 & $65.19(53.82)$ & 34.81 \\
\hline $10 \mathrm{~min}$ & 28.27 & 23.49 & 100.00 & 50.32 & 64.53 & $53.32(46.88)$ & 46.68 \\
\hline $15 \mathrm{~min}$ & 6.37 & 9.36 & 100.00 & 8.89 & 50.16 & $34.96(36.23)$ & 65.04 \\
\hline Control & 100.00 & 100.00 & 100.00 & 100.00 & 100.00 & $100.00(89.96)$ & - \\
\hline Mean & $44.00(41.54)$ & $42.28(40.54)$ & $100.00(89.96)$ & $56.22(48.55)$ & 74.34 (59.54) & - & - \\
\hline
\end{tabular}

CD ( $p=0.05)$; Treatment: 0.360; Test pathogen: 0.403; Treatment $\times$ Test pathogen: 0.806 ; ${ }^{*}$ Figures in parentheses are arc sine transformed values

al., 1993).

\section{Conclusion}

Treating apples in water at $48^{\circ} \mathrm{C}$ for 3 min was highly effective in controlling various fungal decays under study with per cent control of $70.79 \%$ and the effectiveness got reduced on raising this temperature by only $4{ }^{\circ} \mathrm{C}$. UV exposure of 15 min was highly effective in controlling various fungal rots under study with per cent control of $65.04 \%$, respectively. Thus, physical control measures viz. hot water dippings and UV irradiation can be taken as alternatives for the control of storage rots of apple fruits.

\section{References}

Akamine, E.K., Arisumi, T., 1953. Control of post harvest storage decay of fruits of papaya (Carica papaya L.) 
with special reference to the effect of hot water. In: Proceedings of the American Society for Horticultural Science 61, 270-274.

Amiri, A., Bompeix, G., 2011. Control of Penicillium expansum with potassium phosphite and heat treatment. Crop Protection 30, 222-227.

Barkai-Golan, R., 2001. Post harvest diseases of fruits and vegetables-development and control. Elsevier Science B.V., Netherlands, 418.

Burchill, R.T., 1964. Hot water as a possible post harvest control of Gloeosporium rots of stored apples. Plant Pathology 13, 106-107.

Couey, H.M., Follstad, M.N., 1966. Heat pasteurization for control of post harvest decay in fresh strawberries. Phytopathology 56, 1345-1347.

Drake, S.R., Sanderson, P.G., Neven, L.G., 1998. Quality of apples and pears after exposure to irradiation as a quarantine treatment. USDA, ARS-TFRL. Online: http:// mbao.org/1998airc/079drake.pdf Retrieved, 18-112013.

Droby, S., Chalutz, E., Horv, B., Cohen, L., Gabai, V., Wilson, C.L., Wisniewski, M.E., 1993. Factors affecting UVinduced resistance in grapefruit against the green mould decay caused by Penicillium digitatum. Plant Pathology 2, 418-424.

Fallik, E., Grinberg, S., Gambourg, M., Klein, J.D., Lurie, S., 1995. Prestorage heat treatment reduces pathogenicity of Penicillium expansum in apple fruit. Plant Pathology 45, 92-97.

Granger, K., Horne, A.S., 1924. A method of inoculating the apples. Annals of Botany 38, 212-215.

Liu, J., Sui, Y., Wisniewski, M., Droby, S., Tian, S., Norelli, J., Hershkovitz, V., 2012. Effect of heat treatment on inhibition of Monilinia fructicola and induction of disease resistance in peach fruit. Postharvest Biology and Technology 65, 61-68.

Lurie, S., Klein, J.D., 1990. Heat treatment of ripening apples: differential effects on physiology and biochemistry. Physiologia Plantarum 78, 181-186.

Martinelli, F.M., Busconi, F., Camangi, C., Fogher, A., Stefani, Sebastiani, L., 2008. Ancient Pomoideae (Malus domestica Borkh. and Pyrus communis L.) cultivars in "Appenino Toscano" (Tuscany, Italy): molecular (SSR) and morphological characterization. Caryologia 61, 320-331.

Maxin, P., Fieger-Metag, N., Benduhn, B., Kruse, P., Eyne, P.H., 2006. Hot water dipping in Northern Germany-on farm results after four years of scientific work. In: Boos, M.H. (ed.): Proceedings of the $12^{\text {th }}$ International Conference on Cultivation Technique and Phytopathological Problems in Organic Fruit-Growing. FOKO, Weinsberg, Germany, 118-120.

Maxin, P., Klopp, K., Huyskens-Keil, S., Ebert, G., 2005. Control of post harvest decay in organic grown apples by hot water treatment. Acta Horticulturae 682, 2153-2158.

Maxin, P., Weber, R.W.S., Pedersen, H.L., Williams, M., 2012. Hot-Water Dipping of Apples to Control Penicillium expansum, Neonectria galligena and Botrytis cinerea: Effects of Temperature on Spore Germination and Fruit Rots. European Journal of Horticulture Science 77, 1611-4426.

Neri, F., Mari, M., Brigati, S., Bertolini, P., 2009. Control of Neofabraea alba by plant volatile compounds and hot water. Postharvest Biology and Technology 51, 425-430.

Pavoncello, D., Lurie, S., Droby, S., Porat, R., 2001. A hot water treatment induces resistance to Penicillium digitatum and promotes the accumulation of heat shock and pathogenesis-related proteins in grapefruit flavedo. Physiologia Plantarum 111, 17-22.

Porat, R., Daus, A., Weiss, B., Cohen, L., Fallik, E., Droby, S., 2000. Reduction of postharvest decay on organic citrus fruit by a short hot water brushing treatment. Postharvest Biology and Technology 18, 151-157.

Schirra, M., D’Hallewin, G., Ben-Yehoshua, S., Fallik, E., 2000. Host-pathogen interactions modulated by heat treatment. Postharvest Biology and Technology 21, 71-85.

Sommer, N.F., Maxie, E.C., Fortlage, R.J., 1964. Quantitative dose response of Prunus fruit decay to gamma irradiation. Radiation Botany 4, 309-316.

Spotts, R.A., Chen, P.M., 1987. Prestorage heat treatment for control of decay of pear fruit. Phytopathology 77, 1578-1582.

Srivastava, M.P., Tandon, R.N., 1968. Influence of temperature on Botryodiplodia rot of citrus and sapodilla. Indian Phytopathology 21, 195-197.

Trierweiler, B., Schirmer, H., Tauscher, B., 2003. Hot water treatment to control Gloeosporium disease during longterm storage. Journal of Applied Botany 77, 156-159.

Wang, C.Y., Bowen, J.H., Weir, I.E., Allan, A.C., Ferguson, I.B., 2001. Heat-induced protection against death of suspension-cultured apple fruit cells exposed to low temperature. Plant Cell Environment 24, 1199-1207.

Woolf, A.B., Ferguson, I.B., 2000. Postharvest responses to high fruit temperatures in the field. Postharvest Biology and Technology 21, 7-20. 